\title{
In Vitro Effiacy Of Different Antibiotic Combinations On Aminoglycoside- Resistant Acinetobacter Baumannii
}

\author{
Sarah Ibrahim Saad Ibrahim , Ferialla abdelhamid', Neveen Mohamed salah ${ }^{2}$, \\ Mohamed elsayed ${ }^{3}$.
}

${ }^{1}$ Assistant Prof. of Microbiology Botany and Microbiology deparment ,faculty for wamen for arts.Scinces and Education -Ain Shams Univerisity.

${ }^{2}$ Assistant Prof. of Microbiology,Microbiology deparment ,National Organization for Drug Control and Research (NODCAR).

3 Assistant Prof. of Microbiology,Microbiology deparment ,National Organization for Biological Control and Research (NODCAR).

\begin{abstract}
:
The potential synergy of combination of $\beta$-lactams(ceftriaxone, cefixime, carpabenem, and impenim)and aminoglycosides were tested against multidrug resistant Acinetobacter baumannii. Two-hundred bacterial pathogens were collected from Egyptian hospitals from various infection sites.One hundred and twentytwo isolates $(60 \%)$ were resistant for aminoglycosides.Out of two-hundred strains,130 Acinetobacter baumannii strains (65\%), were impenim resistant and nearly 180 Acinetobacter baumannii strains (90\%),were resistant to cephalosporin. The MIC was determined for Acinetobacter baumanni istrains(32 to >512 $\mathrm{mg} / \mathrm{ml})$. In the checkerboard method, 38 combination from 45 combinations showed synergism for more than $60 \%$ of the tested strains but only two demonstrated antagonism against 5 of tested strains. i.e. the ratio of synergy were detected for gentamycin with impenim, ceftriaxone and cefixime was $100 \%$. Also synergism observed in case of combination between amakacin and tobramycin with ceftriaxone and cefixine with $100 \%$,but in case of combination of tobramycin with imipenem showed ratio of synergy is $50 \%$ Whereas, combination between amakacin/impenim showed antagonism .
\end{abstract}

Keywords: Acinetobacter baumannii, aminoglycosides, $\beta$-lactams combination. Synergy.

\section{Corresponding author: Sarah Ibrahim Saad Ibrahim}

\section{E-mail : Sa_saadalla94@hotmail.com}




\section{Introduction:}

Acinetobacter baumannii is considered as one of the major causes of nosocomial outetbreaks and is resistant to most available antibiotics. Aminoglycosides wasatreatment options forAcinetobacter infections but their resistance has increased in the recent years. Antimicrobial resistance in Gram-negative bacteria are one of the three greatest threats to human health(Allen, et al 1995, Bergogne-Berezin, et al., 1987). Acinetobacter bamanunii is one of the three most challenging Gram-negative pathogens, especially in intensive care units. Approximately 14,000 critically ill patients with $A$. baumannii infections were highly associated with increased mortalityand high morbidity rates(Bouvet, and. Grimont. 1986).

It is often causes a multiple infections likebloodstream, respiratory tract, and wound infections (Mortensen et al., 2014; Peleg et al., 2008;Allen, et al 1995, Anstey, et al 1992,Bouvet, et al 1987, Bouvet., et al1990). Multidrug-resistant A.baumannii strains are a critical concern, resulting in a major outbreaks worldwide.Traditionally, $\beta$-lactams and aminoglycosides were successfully used to treat susceptibleA. baumannii (Chopade, et al., 1985), but unfortunately, with increasing abuse, strains have emerged resistant to virtually all antibiotics in monotherapy (Crombach,,et al 1989). Nowadays carbapenems were hitherto considered the treatment of choice against severe A. baumannii infections, carbapenemresistant A. baumannii isolates are rapidly increasing (Devaud, et al 1982). Aminoglycoside monotherapy was caused significant killing of A. baumannii but followed by rapid and extensive resistance emergence in vitro and in patients (Douboyas,.., et al 1994, Drusano,. 1991, Eliopoulos, and Eliopoulos. 1989). $\beta$-Lactam antibiotics are widely used and very safe, as well as clinicians are well trained on the safe use of aminoglycosides (Joly-Guillou, et al 1987). Aminoglycoside and $\beta$-lactam antibiotics have different mechanisms of action and resistance; there is no efflux pump which affects both of these antibiotic classes in $A$. baumannii (Joly-Guillou et al 1990). This suggests that $\beta$-lactams may kill aminoglycosideresistant bacteria and vice versa (Klastersky, J. et al 1977,Marques, et al 1995) Additionally, $\beta$-lactam disrupt the outer membrane of A. baumanniiin which enhance the target site penetration of aminoglycoside, since the outer membrane of $A$. baumannii is approximately 2to 7-fold less permeable than that of Pseudomonas aeruginosa and approximately 50-fold less permeable than that of Escherichia coli (Martinez-Martinez, et al 1995, Meyers, et al 1991). The high rates of resistance in A. baumannii highlight the necessary need for an alternative treatment options, such as rationally optimized combination therapies.Therefore, we conducted in this study to check the susceptibility pattern of resistant Acinetobacter baumannii against commonly available antibiotics in our set up and identify synergistic 
bacterial killing and overcome of resistance for combinations of a $\beta$-lactam with an aminoglycoside against $A$. baumannii as substantial treatment options.

\section{MATERIALS AND METHODS:}

\section{Collection and identificationof bacterial isolates.}

Two hundred bacterial isolates were collected from clinical samples (blood, urine, stool, sputum, wound and endotracheal tube infection)from microbiological laboratories belonging to four hospitals in Cairo, Egypt (Nasser Institute, El-Kasr Al-Ainy Hospital, Abou El-Reesh, El-Haram Hospital, and Hussaini Hospital) along the period from November2016 to December 2017.All bacterial isolates were identified by conventional methods confirmed using OXA-51 gene that is intrinsic to the species, using the primers sequences as following(Woodford, N,et al 2006)::

\section{5"-TAATGCTTTGAT CGGCCTTG-3"}

3"-TGGATTGCACTTCATCTTGG-5"

\section{Antimicrobial Susceptibility testing}

Antimicrobial susceptibility testing of identified Acinetobacterstrains was carried out by disk diffusion method using the Kirby-Bauer technique1966 (Meyers, B. R., et al 1991) and as the recommendations of CLSI document M2-A41 (NCLSI 1994). Antibiotics to be tested; were selected referring to CLSI document M100-S28 (CLSI, 2018), and they included the first and second line antibiotics commonly used for treatment of Acinetobacter infections. The tested antibiotics included; gentamicin, tobramycin, amikacin, meropenem , imipenem , Amoxycillin Clavulanate, cefixime, Ampicillin, Cefoperazone, Cefoperazone-Sulbactam, Cefotaxime, Cefoxitin, Ceftazidime, Ceftriaxone, Cefturoxime, Ciprofloxacin, Cotrimoxazole, Levofloxacin, Piperacillin, Oflaxacin, Norfloxacin.

3. Determination of Minimum Inhibitory concentrations (MICs)of antibiotics against Acinetobacter baumannii isolates:

Minimum Inhibitory Concentrations (MICs)of different antibiotics againstclinical $A$. baumannii strains $\left(1.5 \times 10^{\wedge} 8 \mathrm{CFU} / \mathrm{ml}\right)$ were determined by broth microdilution method in Mueller-Hinton broth MHB (Oxoid, USA) according to Clinical and Laboratory Standards Institute methods (CLSI 2014).The different antibiotic standards include: cefixime, ceftriaxone, imipenem, Gentamicin, Tobramycin and Amikacin .The stock solutions of antibiotic were prepared using following equation(Eucast,2013,Anderws,2001.): 
Weight of powder $(\mathrm{mg})=[$ Volume of solution $(\mathrm{ml}) \times$ Concentration $(\mathrm{mg} / \mathrm{L})] /$ Potency of powder (mg/g)

\section{Combinations of antibiotics using Checkerboard method:}

Combination of antibiotics was done by using checkerboard method(Eliopoulos and moellering, 1996) for five selected multidrug-resistantAcinetobacter baumannii strains namely, ACN1N, ACN4, ACN12, ACN15 and ACN18. The checkerboard dilution test is widely used in vitro for the evaluation of combination potential synergetic effect of both individual and combined antibiotics as represent by FIC index. The concentration range of each used antibiotic combination tested in range from 1/4 XMIC up to $2 \mathrm{X}$ MIC dilution.Each test was performed in triplicate with starting inoculum at concentration of $5 \times 10^{\wedge} 5 \mathrm{CFU} / \mathrm{ml}$.

The fractional inhibitory concentration (FIC) index is a mathematical expression used to represent the interaction of antibiotics, and was calculated for each antibiotic in each combination using the following formula.

\section{FIC index=FICA + FICB}

1. FICA $=$ MIC of drug A in combination/ MIC of drug A alone

2. $\mathbf{F I C B}=$ MIC of drug B in combination/ MIC of drug B alone

The FIC indices were interpreted as:

Synergy (was defined when) $=\mathrm{FIC} \leq 0.5$.

Additive or indifferent (was defined when) $=\mathrm{FIC}>0.5 \leq 4.0$.

Antagonism (was defined when) $=$ FIC $>4.0$.

The checkerboard method (Microtitre method) was performed in 96 well microtitre plates containing Cephalosporins plus aminoglycosides and Carbapenem plus aminoglycosides antibiotics.

\section{Result:}

In the present study,we collected two hundred bacterial pathogens from Egyptian hospitals from different infection sites. However, the most common clinical specimen were endotracheal infections followed by sputum, blood, urine and wounds .The isolates were identified using conventional methods depending on cultural and biochemical characteristics on blood and MacConkey agar medium and as oxidase negative and catalase positive isolates. The positive 180 Acinetobacter isolates were confirmed using PCR detection of bla-oxa-51 gene with amplicon size $353 \mathrm{bp}$ that is characteristic for Acinetobacter baumannii. The phenotypic resistance patterns represented in Table (1), which showed that A. baumannii stains are resistant to aminoglycoside, $\beta$-lactam, Fluroquinolons and Sulfa drugs in a variable degrees of resistance as assessed by disk diffusion methods. Out of two hundred A. baumannii 
strains, one hundred and twenty two strains (60\%) were resistant to aminoglycosides,130strains was impenim resistant and nearly 170 strains were resistant to cephalosporin. A.baumanniistrains were exhibited maximal resistance against $\beta$-lactam $91 \%$, and minimal degree resistance against ofloxacin $46.5 \%$ and intermediate degree resistance against aminoglycosides (53\%).Additionally,the resistance rate of A. baumanniiwas ranged from $35.5 \%$ to $99 \%$ and sensitivity rate was from $1 \%$ to $60.5 \%$ (Figure 1 ).

It is proposed that the phenotypic pattern of the selected five A.baumanniistrains, all five strains were resistant to aminoglycosides $(100 \%)$ as well as five strains were resistant to fourteen antibiotics (100\%) except norfloxacin that showed $80 \%$ degree of resistance.

In order to study the overcome of resistance problem, it was decided to focus on evaluate the MICs of selected antibiotic alone and in combination. In table (3) showed the MIC values of antibiotics belonging to aminoglycoside and $\beta$-lactam groups. All strains showed high MICs for all antibiotics tested in a range from 128 to $\geq 512 \mu \mathrm{g} / \mathrm{ml}$ for aminoglycoside groups and $\beta$ lactam groups in a range from 64 to $\geq 512 \mu \mathrm{g} / \mathrm{ml}$.

In vitro antibacterial activity of tested antibiotics combination against multidrug resistancesA.baumannii showed in table (4) by employing checkerboard method. Synergism was achieved in all combination using gentamycin (100\%) for five tested strains. However, $93.33 \%$ and $66.66 \%$ was found for all combination using tobramycin and amikacin, respectively. In addition, according to FICindex, cephalosporins antibiotics were found to have synergistic effect when used with aminoglycosides other than carbapeneme (imipenem). Among combinations, antagonism was seen in $40 \%$ of selected strain in combination between amikacin and imipenem(AK \&IMP) according to FIC index while additive or indifferent effect was observed in $60 \%$ and $40 \%$ of selected strains with amikacin and imipenem (AK plus IMP) and tobramycin and imipenem (TOB plus IMP), respectively i.e. Synergism was most observed in all antibiotic combination against tested strains whereas the least effective combination was to amikacin plus imipenem.

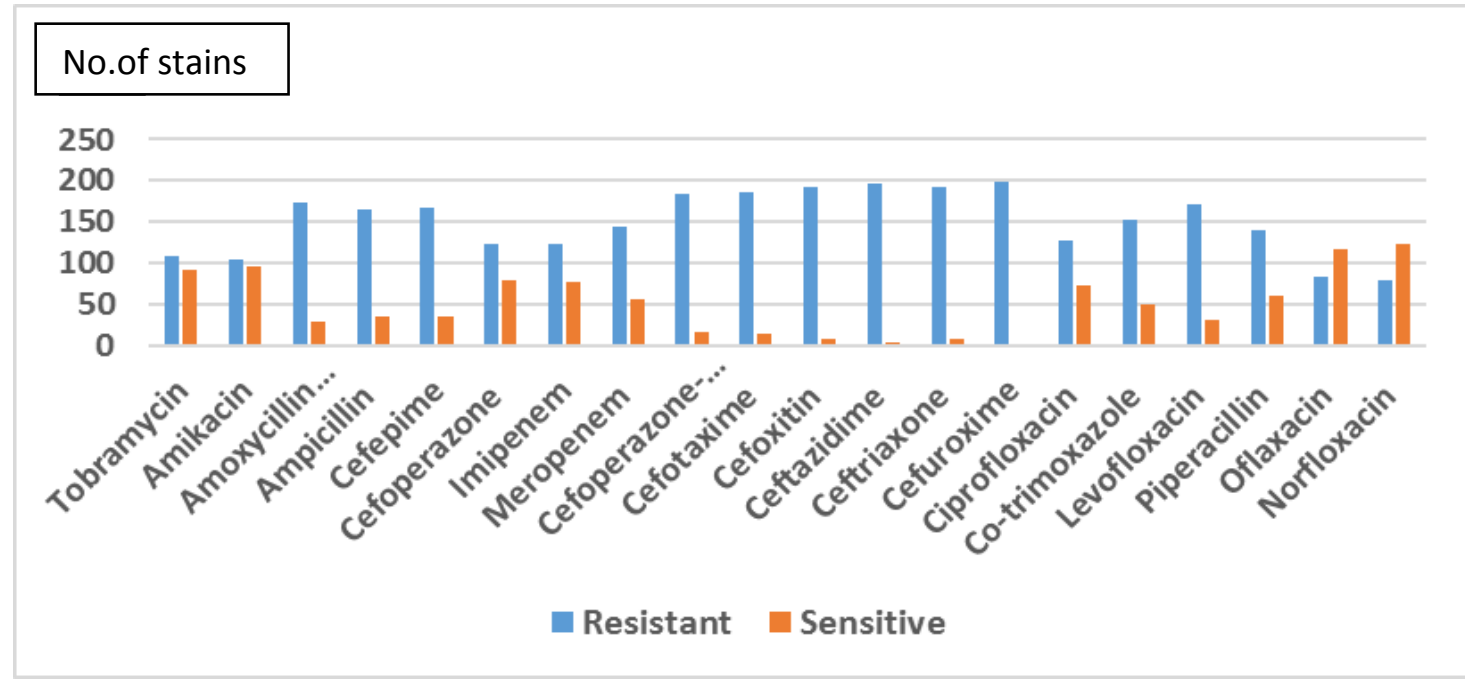


Figure (1) Phenotypic resistant index of Acinetobacter baumannii strains.

Table (1): percentage of resistance patterns of aminoglycosides resistant Acinetobacterstrains

\begin{tabular}{|c|c|c|c|c|c|c|}
\hline \multirow{2}{*}{\multicolumn{2}{|c|}{ Antibiotic groups }} & \multirow{2}{*}{ Antibiotics } & \multicolumn{2}{|c|}{ Sensitive(S) } & \multicolumn{2}{|c|}{ Resistance (R) } \\
\hline & & & $\%$ & No. & $\%$ & No. \\
\hline \multirow{3}{*}{\multicolumn{2}{|c|}{ Aminoglycosides }} & Gentamicin (GN) & 39.5 & 79 & 60.5 & 121 \\
\hline & & Tobramycin (TOB) & 45 & 90 & 55 & 110 \\
\hline & & Amikacin (AK) & 47 & 94 & 53 & 106 \\
\hline \multirow{13}{*}{$\begin{array}{l}\beta- \\
\text { lactam }\end{array}$} & \multirow{3}{*}{ Penicillins } & $\begin{array}{l}\text { Amoxycillin/clavulanate } \\
\text { (AMC) }\end{array}$ & 12.5 & 25 & 87.5 & 175 \\
\hline & & Ampicilin (AMP) & 17.5 & 35 & 82.5 & 165 \\
\hline & & Pipracillin (PRL) & 43 & 86 & 57 & 114 \\
\hline & \multirow{8}{*}{$\begin{array}{l}\text { Cephalospo } \\
\text { rins }\end{array}$} & Cefepime (FEP) & 17 & 34 & 83 & 166 \\
\hline & & Cefoperazone (CEP) & 39 & 78 & 61 & 122 \\
\hline & & Cefoperazone-Sulbactam & 8.5 & 12 & 91.5 & 183 \\
\hline & & Cefotaxime (CTX) & 12 & 24 & 88 & 176 \\
\hline & & Cefoxitin (FOX) & 4 & 8 & 96 & 192 \\
\hline & & Ceftriaxone (CRO) & 2 & 4 & 98 & 196 \\
\hline & & Cefturoxime (CXM) & 4 & 8 & 96 & 192 \\
\hline & & cefixime $(\mathrm{CFM})$ & 1 & 2 & 99 & 198 \\
\hline & \multirow{2}{*}{$\begin{array}{l}\text { Carbapene } \\
\mathrm{m}\end{array}$} & Imipenam (IMP) & 35 & 70 & 65 & 130 \\
\hline & & Meropenom (MEM) & 27 & 54 & 73 & 146 \\
\hline \multirow{4}{*}{\multicolumn{2}{|c|}{$\begin{array}{l}\text { Quinolones } \\
\text { \&Fluroquinolons }\end{array}$}} & Ciprofloxacin (CIP) & 23.5 & 47 & 76.5 & 153 \\
\hline & & Levofloxacin (LEV) & 9.5 & 19 & 90.5 & 181 \\
\hline & & Ofaxacin (OFX) & 53.5 & 107 & 46.5 & 93 \\
\hline & & Norfloxacin (NOR) & 60.5 & 121 & 39.5 & 79 \\
\hline \multicolumn{2}{|c|}{ Sulfa drugs } & Co-trimoxazole (STX) & 24.5 & 49 & 75.5 & 151 \\
\hline
\end{tabular}


Table (2) phenotypic resistance patterns of selected Acinetobacter strains

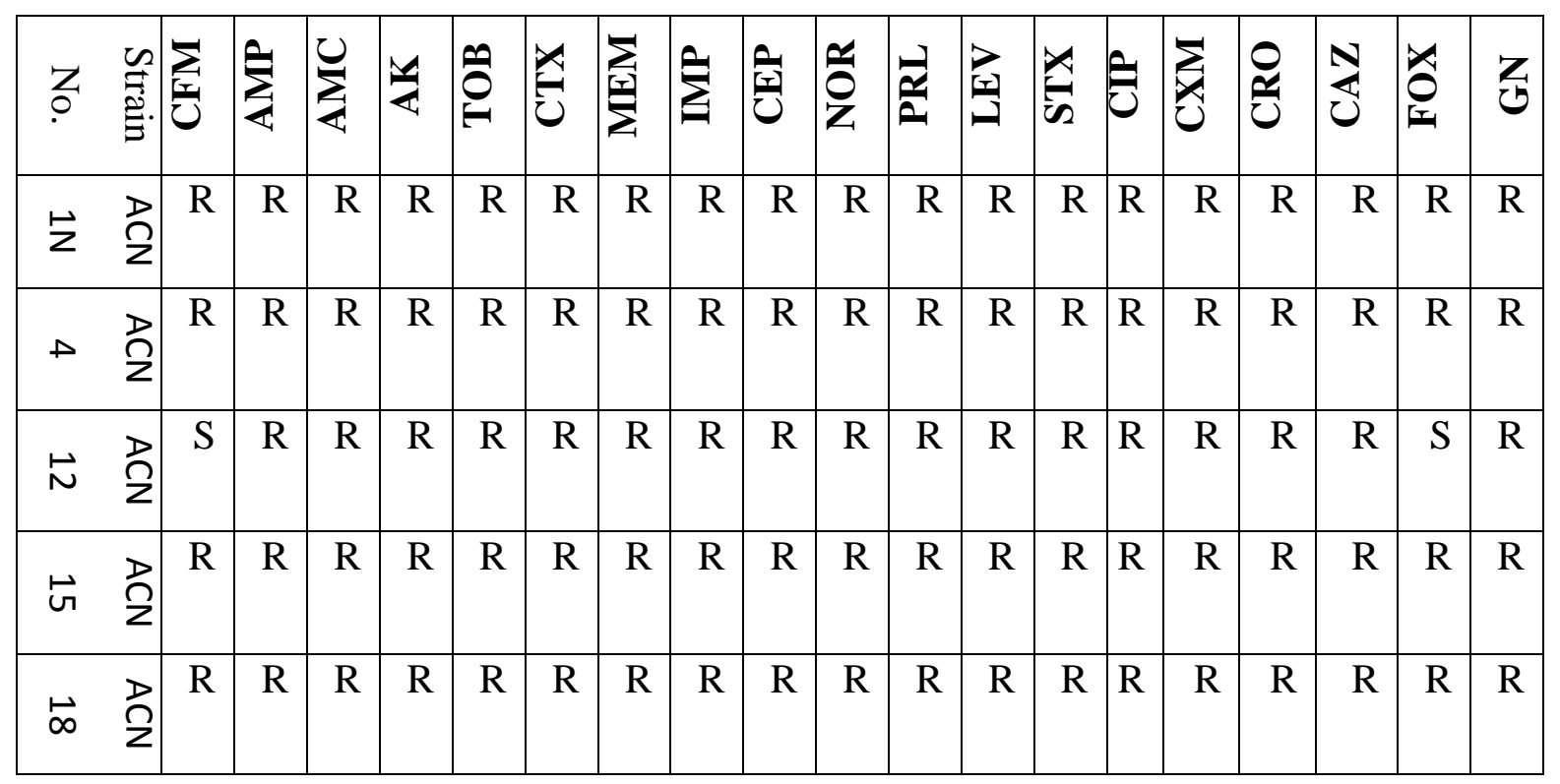

R: Resistance S: Sensitive, GN: gentamicin, TOB: tobramycin, AK: amikacin, MEM: meropenem, IMP: imipenem, AMC: Amoxycillin Clavulanate, CFM: cefixime, CRO: Ceftriaxone, AMP: Ampicillin, CEF: Cefoperazone, Cefoperazone-Sulbactam, CTX: Cefotaxime, FOX: Cefoxitin, CAZ: Ceftazidime, CXM: Cefturoxime, CIP: Ciprofloxacin, STX: Co-trimoxazole, LEV: Levofloxacin, PRL: Piperacillin, OFX: Oflaxacin, NOR: Norfloxacin.

Table (3): MICs of tested antibiotics against selected Acinetobacter baumannii strains

\begin{tabular}{|l|c|c|c|c|c|c|}
\hline \multirow{2}{*}{$\begin{array}{c}\text { Acinetobacter } \\
\text { baumannii }\end{array}$} & \multicolumn{5}{|c|}{ Concentration of antibiotics (mg/L) } \\
\cline { 2 - 7 } \multicolumn{1}{c|}{ Strains } & \multicolumn{2}{|c|}{ Aminoglycosides group } & \multicolumn{3}{c|}{$\beta$-lactam group } \\
\cline { 2 - 7 } ACN1N & $\geq 512$ & $\geq 512$ & $\geq 512$ & 64 & $512 \geq$ & $512 \geq$ \\
\hline ACN4 & $\geq 512$ & 128 & 128 & $512 \geq$ & $>512$ & $>512$ \\
\hline ACN12 & 256 & $\geq 512$ & $>512$ & 128 & $512 \geq$ & $512 \geq$ \\
\hline ACN15 & $\geq 512$ & 128 & 128 & 256 & $>512$ & 256 \\
\hline ACN18 & $\geq 512$ & 256 & 256 & 128 & 256 & $>512$ \\
\hline
\end{tabular}


Table (5) : Combination of aminoglycosides and $\beta$-lactamsagainstAcinetobacterbaumanniistrains.

\begin{tabular}{|c|c|c|c|c|c|c|c|c|c|c|c|c|c|c|c|c|}
\hline$\dot{\Omega}$ & \multicolumn{3}{|c|}{$\mathbf{1 N}$} & \multicolumn{3}{|c|}{4} & \multicolumn{4}{|c|}{12} & \multicolumn{3}{|c|}{15} & \multicolumn{3}{|c|}{18} \\
\hline 莫 & ن் & $\underset{I}{U}$ & 党 & ن் & $\underset{U}{U}$ & : & 巳் & & $\frac{U}{I}$ & 蛋 & ن̈ & $\stackrel{U}{U}$ & 㟒 & 官 & $\frac{U}{I}$ & 总 \\
\hline 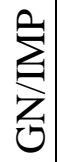 & $\frac{\infty}{n}$ & $\frac{\infty}{\stackrel{\infty}{n}}$ & $\sim s$ & $\frac{t}{b}$ & $\stackrel{n}{0}$ & $\sim s$ & $\frac{t}{b}$ & & ஜे & $\sim s$ & $\frac{ \pm}{\sigma}$ & $\stackrel{+}{0}$ & $\sim s$ & $\underset{\sigma}{\Delta}$ & $\begin{array}{l}0 \\
0 \\
0\end{array}$ & $\sim$ \\
\hline 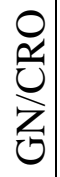 & $\underset{\forall}{\forall}$ & $\stackrel{n}{0}$ & $\Omega$ & $\frac{\partial}{\partial}$ & $\begin{array}{l}\overline{0} \\
\stackrel{0}{0}\end{array}$ & $\Omega$ & N & $\stackrel{d}{\exists}$ & $\hat{n}$ & $\sim$ & ก & $\frac{\infty}{\infty}$ & $\sim$ & $\frac{\partial}{\partial}$ & $\stackrel{0}{0}$ & $\sim$ \\
\hline 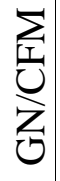 & $\frac{t}{\infty}$ & $\stackrel{ \pm}{0}$ & $\Omega$ & $\underset{\forall}{\stackrel{ナ}{f}}$ & $\stackrel{m}{0}$ & $\Omega$ & $亠$ & $\stackrel{\simeq}{\beth}$ & $\underset{\sim}{\infty}$ & $\Omega$ & $\infty$ & 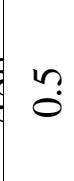 & \&s & $\stackrel{\nabla}{\forall}$ & $\frac{0}{0}$ & $\sim$ \\
\hline$\underset{⿱ 亠 䒑}{\frac{n}{2}}$ & $\frac{d}{n}$ & $n$ & ${ }^{00}$ & 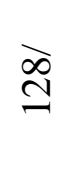 & 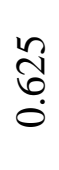 & $\frac{\pi}{2}$ & 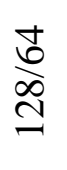 & & 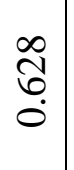 & $\frac{\pi}{4}$ & $\frac{\infty}{\underset{n}{\sim}}$ & $\stackrel{n}{\forall}$ & ${ }^{\infty} 0$ & 可 & $\frac{n}{0}$ & $\overline{4}$ \\
\hline 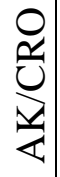 & $\underset{\sigma}{\Delta}$ & 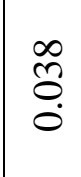 & $\sim$ & $\frac{\infty}{\underset{\infty}{(}}$ & $\stackrel{\infty}{n}$ & $\Omega$ & $亠$ & $\stackrel{d}{d}$ & $\stackrel{n}{a}$ & $\Omega$ & 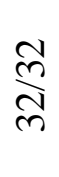 & $\begin{array}{l}\text { N } \\
\text { ஸి } \\
0\end{array}$ & Us & $\grave{\infty}$ & d & $\sim s$ \\
\hline 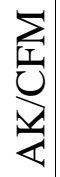 & 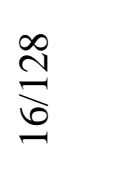 & $\stackrel{\infty}{\stackrel{0}{0}}$ & $\sim$ & $\frac{\infty}{\underset{\infty}{\sim}}$ & $\stackrel{t}{0}$ & $\sim$ & 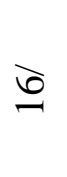 & ल & $\stackrel{\infty}{\stackrel{\infty}{0}}$ & $\sim$ & శె & $\stackrel{n}{0}$ & $\sim s$ & $\stackrel{0}{\gamma}$ & $\stackrel{0}{0}$ & $\sim$ \\
\hline 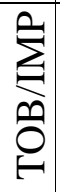 & 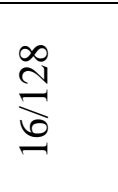 & $\underset{0}{0}$ & $\frac{8}{4}$ & $\begin{array}{l}\text { dे } \\
\text { nె }\end{array}$ & $\stackrel{n}{n}$ & $\Omega$ & $\approx$ & ఫૈ & $\stackrel{n}{n}$ & 定 & 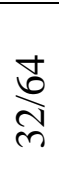 & $\tilde{0}$ & $\sim$ & $\infty$ & 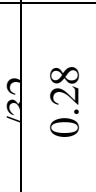 & $\sim$ \\
\hline$\frac{\tilde{c}}{\tilde{v}}$ & $\underset{\forall}{\stackrel{ナ}{f}}$ & $\stackrel{\sigma}{0}$ & $\Omega$ & $\underset{\forall}{\stackrel{ナ}{f}}$ & ڤે & $\Omega$ & $\stackrel{\curvearrowright}{\gamma}$ & & ọ & $\sim$ & $\stackrel{\curvearrowright}{\gamma}$ & o̊. & $\Omega$ & $\infty$ & 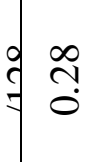 & $\sim$ \\
\hline$\frac{\stackrel{I}{\mathcal{U}}}{\frac{\tilde{m}}{0}}$ & $\stackrel{\curvearrowright}{\gamma}$ & $\stackrel{5}{0}$ & $\sim$ & $\stackrel{\nabla}{\partial}$ & $\stackrel{n}{\varrho}$ & $\sim$ & $\underset{\sigma}{\Delta}$ & & ڤై & $\sim$ & $\frac{t}{6}$ & $\frac{ \pm}{0}$ & $\Omega$ & $\infty$ & $\frac{d}{0}$ & $\sim$ \\
\hline
\end{tabular}

FIC: fractional inhibitory concentration, S : Synergy, Ad : Additive, Ag : Antagonism. 


\section{Discussion:}

Aminoglycosides resistance in Acinetobacter spp. has emerged as a significant health problem due to the therapeutic option was very limited. Aminoglycoside resistance is common in Acinetobacterspp. and that was in agreement with Lambert etal.,(1997). Who mentioned that the inactivation of the antibiotic was carried out by specific modifying enzymes such as acetyltransferases, phosphotransferases, and adenylyltransferases. Acinetobacter spp are frequently resistant to multiple antimicrobial agents; there are several reports on strains resistant to most clinically relevant drugs (Lu 2008, Giamarellou, etal., 2008). Differences in antibiotic susceptibility have been observed between countries, probably as a result of environmental factors and different patterns of antimicrobial usage. Gaur and co-works reported more than $80 \%$ of isolates to be resistance to cephalosporin, aminoglycosides, and quinolones especially second and third-generation (Gaur et al., 2008). The present study showed the resistance rate to imipenem, ampicillin/tobramycin, ceftazidime, cefixime, gentamicin, amikacinand ciprofloxacin were more than $90 \%$ in the selected multidrugresistant Acinetobacterbaumannii this observation is consistent with those of (Livermore, 2002).

The obtained result indicate that, endotracheal infections were the most common clinical specimen of Acinetobacter spp. The frequency of isolation and variety of bacteria found in clinical specimens in different countries widely varies (Shiri et al, 2005; Van Looveren\&Goossens 2004). Potential risk factors for colonization or infection of hospitalized patients with multidrug-resistant Acinetobacterstrains include length of ICU stay, underlying diseases, or conditions, exposure to carbapenems or third-generation cephalosporin, hospitalization and using urinary catheterization (Cisneros et al. 2005; Prashanth \& Badrinath,2006). The findings showed that clinical isolates of Acinetobacter spp. in our hospital carrying various kinds of aminoglycoside resistance. Once of the common ways to overcome antibiotic resistance was combination of gentamycin, amikacin and tobramycin with imipenem, ceftriaxone and cefixime. The results virtually extend to the results of previous studies on aminoglycosides in combination with beta lactam against Acinetobacter baumnnii, the checkerboard method was used to assess the synergy between antimicrobials against Acinetobacterspp. in many of these studies antibiotic combinations have demonstrated the synergistic or bactericidal effects against bacteria that have been resistant to the individual drugs by using checkerboard methods. For example, synergistic effects have been demonstrated for double and triple antibiotic combinations including an aminoglycoside, an 
anti-pseudomonal beta-lactam, colistin, a fluoroquinolone, a macrolide, or rifampin against multidrug-resistant Pseudomonas spp. (Fish et al., 2008;Saiman et al., 2002;Aoki et al., 2009). Double and triple antibiotic combinations including an aminoglycoside, ampicillin/sulbactam, a carbapeneme, colistin, rifampin, tigecycline, or vancomycin have been effective against multidrug-resistant Acinetobacter spp. (Urbanet al., 2010;Kiffer et al. 2005, Hornsey \&Wareham, 2011) each drug combination was evaluated in duplicate,this study revealed that various antimicrobial combinations could be synergistically in vitro against multidrug-resistant of most Acinetobacter spp. The checkerboard method is employed for this purpose. The results obtained in the study showed the overall rate of synergy in most antibiotic combination.

The combinations of imipenem, ceftriaxone and cefixime with a second group (gentamycin, amikacin and tobramycin) mostly resulted in synergy. Combinations of these antibiotics with gentamycin exhibited synergy in $100 \%$ of the performed tests with the five Acinetobacter spp. in combination between amikacin and $\beta$-lactams (AK plus IMP, CRO and CFM) was 100\% and also in case combination between tobramycin with $\beta$-lactams (TOB plus IMP, CRO and CFM) was $100 \%$. While in $40 \%$ of selected strains antagonism was seen. This observation is consistent with the experience of others (Lim et al., 2008;Prashanth\&Badrinath,2006).

In another study,Tod et al., 2000 by assessing ceftazidime plus tobramycin and piperacillin/tazobactamplus tobramycin combinations against multidrug-resistant P.aeruginosa were evaluated, and synergy ratios of $50 \%$ and $67 \%$, respectively were observed. With respect to fosfomycin, synergistic interactions with other antibacterial drugs were verify in $57 \%$ of the tests, rate similar to that reported previously for multidrug-resistant P.aeruginosa. Fosfomycin enhances the active transport of tobramycin in P.aeruginosa; in vitro synergic actions were also demonstrated for polymyxin $\mathrm{E}$, imipenem, ceftazidimeand ciprofloxacin (Obara \&Nakae, 1991. Landersdorfer et al., 2013).As observed in other studies, the rate of synergy of antibacterial combinations varies according to isolate and is not strictly associated with susceptibility or resistance to imipenem. Comparison of the two multidrugresistant P.aeruginosa revealed more frequent and significant drug MIC reductions for the $46 \mathrm{R}$ isolate than for the $72 \mathrm{R}$ isolate. Thus, it is advisable to test each multidrug-resistant isolate with the different drugs in combination (Shiri et al., 2005).

Among the synergy results, only a few antibacterial combinations have led to sufficient MIC reductions (Chastre et al., 2000). Other authors also noted synergism between third and fourth generation cephalosporin and aminoglycosides (often gentamicin, amikacin and tobramycin) against 30\% to90\% of Enterobacteriaceae (Eliopoulos \&Eliopoulos 1988; Cha, 2008). 
Conclusion:The present study showed that the emergence of Acinetobacter spp. resistance to antimicrobial agents in Eyption hospitals is associated with the spread of more than $60 \%$ of MDR Acinetobacterspp.Bacterial isolates from patients were resistant to aminoglycosides, broad-spectrum cephalosporin, gentamycin, amikacin and tobramycin with imipenem, ceftriaxone, and cefixime and trimethoprim/sulphamethoxazole. Antimicrobial synergy was observed against clinical isolates of MDR Acinetobacter spp. Some drug combinations resulted in sufficientMIC reductions, which suggest that these combinations may be of clinical use for infections of MDR Acinetobactersppas an alternative to antibiotic therapy, suggesting its potential as an among alternative tested aminoglycosides.Therefore, in vitro data must be validated by assessing the clinical performance of combinations of antimicrobial agents before specific recommendations to modify existing treatment guidelines forAcinetobacter infections are possible.

\section{REFERENCES}

Allen, D. M., and Hartman B. J.. 1995. Acinetobacter species, p. 2009-2013.

Anstey, N. M. 1992. Use of cefotaxime for treatment of Acinetobacter infections. Clin. Infect. Dis. 15:374.

Andrews ,J.M.(2001) : Determination of minimumum inhibitory concentrations. $J$ Antimicro chemother :48S1:5-16.

Aoki N, Tateda K, Kikuchi Y, Kimura S, Miyazaki C, Ishii Y. et al.( 2009)Efficacy of colistin combination therapy in a mouse model of pneumonia caused by multidrugresistant Pseudomonas aeruginosa.J Antimicrobial Chemotherapy. 2009; 63:534-42.

Bauer, A.W., Kirby, W.M., Sherris, J.C.\&Turck, M. (1966). Antibiotic susceptibility testing by a standardized single disk method. Am J ClinPathol. 45, 493-496. In G. L. Mandell, J. E. Bennett, and R. Dolin (ed.), Principles and practice baumannii isolated from blood. Diagn. Microbiol. Infect. Dis. 23:105-110.

Bergogne-Berezin, E., Joly-Guillou M. L. , and Vieu J. F.. (1987). Epidemiology of nosocomial infections due to Acinetobacter calcoaceticus. J. Hosp. Infect. 10:105-113.

Bouvet, P. J. M., and Grimont P. A. D.. (1986). Taxonomy of the genus Acinetobacter with the recognition of Acinetobacter baumannii sp. nov. Acinetobacter haemolyticus sp. nov. Acinetobacter johnsonii sp. nov., and Acinetobacter junii sp. nov. and amended descriptions of Acinetobacter calcoaceticus and Acinetobacter lwoffii. Int. J. Syst. Bacteriol. 35:228-240. 
Bouvet, P. J. M., and Grimont P. A. D. - (1987) Identification and bio typing of. Identification and biotyping ofclinical isolates of Acinetobacter. Ann. In'st. Pasteur Microbiol. 138:569-578.

Bouvet, P. J. M., S. Jeanjean, Vieu J.-F. , and Dijkshoorn L.. (1990). Species, biotype, and bacteriophage type determinations compared with cell envelope protein profiles for typing Acinetobacter strains. J. Clin. Microbiol. 28:170- 176.

Cha,R., (2008) In vitro activity of cefepime, imipenem, tigecycline and genamicin, alone and in combination against extended- spectrum beta- lactamase producing Klebsiella pneumonia and Escherichia coli. Pharmacoththerapy 28:295-300

Chang, S. C., Chen Y. C. , Luh K. T. , and Hsieh W. C.. (1995). In vitro activitiesof antimicrobial agents, alone and in combination, against Acinetobacter baumannii isolated from blood. Diagn. Microbiol. Infect. Dis. 23:105-110.

Chastre J \& Trouillet JL. (2000) Problem pathogens (Pseudomonas aeruginosa and Acinetobacter). Semin Respir Infect 15:287-298. doi:10.1053/srin.2000.20944.

Chopade, B. A., Wise P. J. , and Towner K. J. . (1985). Plasmid transfer and behaviour in Acinetobacter calcoaceticus EBF65/65. J. Gen. Microbiol. 131: 2805-2811.

Cisneros JM, Rodríguez-Baño J, Fernández- Cuenca F, Ribera A, Vila J\& Pascual A,. (2005). Risk-factors for the acquisition of imipenem-resistant Acinetobacter baumannii in Spain: a nationwide study. Clin MicrobiolInfect, 11: 874-79.

clinical isolates of Acinetobacter. Ann. In'st. Pasteur Microbiol. 138:569-578.

CLSI (2014). Clinical and laboratory standards institute. Performance standards for antimicrobial susceptibility testing; $18^{\text {th }}$ informational supplement; Wayne, Pennsylvania. CLSI document M100-S24; 2014.

CLSI. (2018). Clinical and laboratory standards institute. Performance standards for antimicrobial susceptibility testing; $18^{\text {th }}$ informational supplement; Wayne, Pennsylvania. CLSI document M100-S28

Crombach, W. H. J., Dijkshoorn L., van Noort-Klaassen M., Niessen J., and van Knippenberg-Gordebeke G.. (1989) . Control of an epidemic spread of amultidrugresistant strain of Acinetobacter calcoaceticus in a hospital. IntensiveCare Med. 85:624631. 
Devaud, M., Kayser F. H. , and Bachi B. . (1982). Transposon-mediated multiple antibiotic resistance in Acinetobacter strains. Antimicrob. Agents Chemother. 22:323-329. Douboyas, Tzouvelekis J., L. S., and Tsakris A.. (1994) In-vitro activity of ampicillin/sulbactam against multi drug-resistant Acinetobacter calcoaceticus var. anitratus clinical isolates. J. Antimicrob. Chemother. 34:298-300.

Eliopoulos, G. M. \& Eliopoulos C. T. , (1988) Antibiotic combinations: should they be tested? Clin Microbiol Rev 1: 139-156.

Eliopoulos, G. M., and Eliopoulos C. T.. (1989). Antibiotic combinations:should they be tested? Clin. Microbiol. Rev. 1:139-156.

Eliopoulos, G. M., and Moellering, R. C. (1996): Antimicrobial combinations, Antibiotics in laboratory medicine, $4^{\text {th }}$ ed. P. 330-396. In Lorian V . (ed.)

Eucast. (2013). Determination of minimum inhibitory concentrations (MICs) of antibacterial agents by broth dilution. Clinical Microbiology and Infection. https:// doi.org/ 10.1046/j. 1469-0691.2003.00790 P 141-160.

Fish DN, Choi MK, and Jung R. (2002) Synergic activity of cephalosporin plus fluoroquinolones against Pseudomonas aeruginosa with resistance to one or both drugs.J Antimicrob Chemother.; 50:1045-9. 33.

van Knippenberg-Gordebeke G.. (1989). Control of an epidemic spread of a multidrugresistant strain of Acinetobacter calcoaceticus in a hospital. Intensive Care Med. 85:624631.

Gaur A, Garg A, Prakash P, Anupurba S \& Mohapatra TM (2008). Observations on carbapenem resistance by minimum inhibitoryconcentration in nosocomial isolates of Acinetobacter species: an experience at a tertiary care hospital in North India. JHealth Popul Nutr, 26(2):183-88.

Giamarellou H, Antoniadou A \& KanellakopoulouK (2008).Acinetobacter baumannii: a universal threat to public health? IntJ Antimicrob Agents 32(2):106-19.

Hornsey M\& Wareham DW.In vivo efficacy of glycopeptide-colistin combination therapies in a Galleria mellonella model of Acinetobacter baumanniiinfection.Antimicrob Agents Chemother. 2011; 55:3534-7. 
Joly-Guillou, M. L., Bergogne-Berezin E., and Vieu J. F.. (1990). A study of the Relationships between antibiotic resistance phenotypes, phage-typing and biotyping of 117 clinical isolates of Acinetobacter sp. J. Hosp. Infect. 16:49-58.

Joly-Guillou, M. L., Bergogne-Berezin E., and Moreau N.. 1987. Enzymatic resistance to b-lactams and aminoglycosides in Acinetobacter calcoaceticus. J. Antimicrob. Chemother. 20:773-776.

Kiffer CR, Sampaio JL, Sinto S, Oplustil CP, Koga Pc \& Arruda AC, et al(2005).In vitro synergy test of meropenem and sulbactam against clinical isolates of Acinetobacter baumannii. Diagn Microbiol Infect Dis.; 52:317-22.

Klastersky, J., Meunier-Carpentier F. , and Prevost J. M. • (1977). Significance of antimicrobial synergism for the outcome of gram negative sepsis. Am. J. Med. Sci. 273:157-167.

Lambert T, Rudant E, Bouvet P\& Courvalin P (1997). Molecular basis of aminoglycosideresistance in Acinetobacter spp. J Med Microbiol, 46: 731-35.

Landersdorfer CB, Ly NS, Xu H, Tsuji BT, Bulitta JB.( 2013). Quantifying subpopulation synergy for antibiotic combinations via mechanism-based modeling and a sequential dosing design. Antimicrob Agents Chemother 57:2343-2351. doi:10.1128/AAC.00092-13.

Lim TP, Ledesma KR, Chang KT, Hou JG, Kwa AL, Nikolaou M, Quinn JP, Prince RA\& Tam VH. (2008). Quantitative assessment of combination antimicrobial therapy against multidrug-resistant Acinetobacter baumannii. Antimicrob Agents Chemother 52:2898-2904. doi:10.1128/AAC.01309-07

Livermore DM.(2002) The impact of carbapenemases on antimicrobialDevelopment and therapy. Curr Opin Investing Drugs. 2002; 3:218-24.

Lu Q, Huang LS, Zhang R, Xu GB\& Zhao XY (2008). Following-up of nosocomial lower respiratory infection in patients with hematological malignance after chemotherapy.

Marques, M. B., J. E. Mangino, B. B. Hines, S. A. Moser, and K. B. Waites. 1995. Investigation of an outbreak of multidrug-resistant Acinetobacter baumanniiin a medical intensive care unit, abstr. L-33, p. 115. In Abstracts of the95th General Meeting of the American Society for Microbiology. AmericanSociety for Microbiology, Washington, D.C.

Martinez-Martinez, L., G. Rodriguez, A. Pascual, A. I. Suarez, and E. J.Perea. (1995). In vitro activity of several antimicrobial combinations against multiresistant Acinetobacter 
baumannii, abstr. E-104, p. 104. In Program and abstracts of the 35th Interscience Conference on Antimicrobial Agents and Chemotherapy. American Society for Microbiology, Washington, D.C.

Meyers, Wilkinson B. R., P., Mendelson M. H. , Walsh S., Bournazos C., and Hirschman S. Z. . (1991). Pharmacokinetics of ampicillin-sulbactam in healthyelderly and young volunteers. Antimicrob. Agents Chemother. 35:2098-2101.

Mortensen E,TrivediK K, Rosenberg J, Cody SH,Long J, JensenBJ, 2014.Multidrugresistant Acinetobacter baumanniïnfection, colonization, andtransmissionrelatedto a long termcarefacilityproviding subacute care. Infect ControlHospEpidemio 2014;35:406-11.

National Committee for Clinical Laboratory Standards. (1994). Performance standards for antimicrobial susceptibility testing; fifth informational supplement. NCCLS document M100-S5, vol. 14. National Committee for Clinical Laboratory Standards, Villanova, Pa.

Obara M\& Nakae T. (1991). Mechanisms of resistance to beta-lactam antibiotics in Acinetobacter calcoaceticus. J Antimicrobial Chemother 28:791-800. doi:10.1093/jac/28.6.791.

Peleg AY,SeifertH,PatersonDL.(2008) Acinetobacter baumannii: emergence of a successful pathogen. Clin Microbiol Rev;21:538-82.

Prashanth K, Badrinath S (2006). Nosocomial infections due to Acinetobacter species: clinical findings, risk and prognostic factors. Ind J Med Microbiol, 24: 39-44.

Saiman L, Chen Y, Gabriel PS\& Knirsch C. (2002) Synergistic activities of macrolide antibiotics against Pseudomonas aeruginosa, Burkholderia cepacia, Stenotrophomonas maltophilia, and Alcaligenes xylosoxidans isolated from patients with cystic fibrosis. Antimicrobial Agents Chemother.; 46:1105-7.

Shiri N-V, Ronen B-A\& Yehuda C (2005). Update on Pseudomonas aeruginosa and Acinetobacter baumannii infections in the healthcaresetting. Curr Opin Infect Dis, 18: 30613.

Tod M, Padoin C\& Petitjean O. (2000). Clinical pharmacokinetics and pharmacodynamics of isepamicin. Clin Pharmacokinet 38:205-223. doi:10.2165/00003088-200038030-00002. 
Urban C, Mariano N\& Rahal JJ.(2010) In vitro double and triple bactericidal activities of doripenem, polymyxin $\mathrm{B}$, and rifampin against multidrug-resistant Acinetobacter baumannii, Pseudomonas aeruginosa, Klebsiella pneumoniae, and Escherichia coli.Antimicrobial Agents Chemother.; 54:2732-4.

Van Looveren M\& Goossens H (2004). ARPAC Steering Group. Antimicrobial resistance of Acinetobacter spp. in Europe. ClinMicrobiol Infect, 10: 684-704.

Woodford, N, Ellington M. J. , Coelho J. M. , Turton J. F. , Wad M. E. , S. Brown S. ,. Amyes S. G. B , and Livermore D. M. (2006). Multiplex PCR for genes encoding prevalent OXA carbapenemases in Acinetobacter spp. Int. J. Antimicrob. Agents 27:351353. 
المخلص العربي

تاثير امتزاج المضادات الحيوية المختلفة علي بكتريا الاسينيتوباكتر بومنييا المقاومة للامينوجليكوسيد بالمختبر. سارةه ابراهيم سعد ابراهيم أ.د.مافريالة عبد الحميد ابوسيف أ.د.م|نفين محمد محمد صالح أ.د.م|محمد السيد علي راشد استاذ دكتور مساعد بكلية البنات جامعه عين شمس بقسم النبات. استاذ دكتور مساعد بالهيئة القومية للرقابة والبحوث الدوائيةبقسم الميكروبيولوجي. استاذ دكتور مساعد بالهيئة القومية للرقابة والبحوث الحيوية بقسم الميكروبيولوجي.

تم عزل مائتين عزلة بكترية من اماكن مختلفة من المستشفيات المصرية وبدر اسة حساسية هذة العزلات وجد منهم حو الي

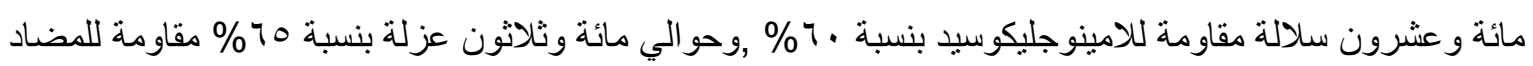

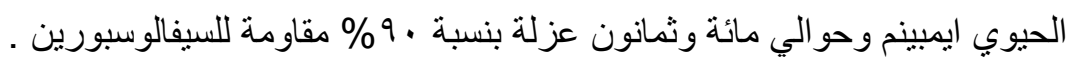

وبقياس الحد الادني للعزلات وجد ان التركيزات الثبطة تترواح ما بين r اه الي r ب ملي جر ام وباستخدام هذة الطريقة لوحظ ان · ج\% كانت نأثبر متعاون بين ايمبينيم وجينتاميسين و . ( \% مع سيفترياكسون وسيفيكسيم. حو الي اثثين من اربعه واربعين لوحظوا انه في تأثثير سلبي ـ اي لايوجد سمة تعاون بين المضادين الحيوين ايمينيم و وايماكسين بينما كان العكس .

مزج المضادات الحيوية في العدوي الخاصة بالمستشفيات التي تسبيها بكتريا الاسينتوباكتر بومنييا باستخدام طريقه الشطرنج (checkboard).

في اختبار امتز اج مجمو عات المضادات الحيوية وهي البيتالكتام (سيفترياكسون , سيفيكسيم , كاربابينيم , وايمينيم ) مع الامينوجليكوسيد ضد عزلات الاسينتوباكتر بومنييا المقاومة لمعظم المضادات الحيوية التي تسبب العدوي بالمستشفيات.

وكذللك ايضا اظهرت النتائج اعلي تأثير تعاون بين اماكيسين مع سيفيرياكسون وسيفكيم بنسبة . . 1 \%ولكن في حالة

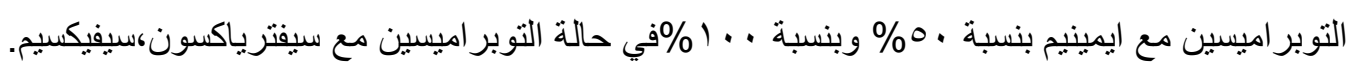

